\title{
The genus Dasydorylas Skevington in Iran, with the description of two new species (Diptera: Pipunculidae)
}

\author{
Behnam MOTAMEDINIA ${ }^{1, *}$, Christian KEHLMAIER ${ }^{2}$, Azizollah MOKHTARI ${ }^{3}$, \\ Ehsan RAKHSHANI ${ }^{4} \&$ Ebrahim GILASIAN ${ }^{5}$ \\ ${ }^{1,3,4}$ Department of Plant Protection, College of Agriculture, \\ University of Zabol, P.O. Box: 98615-53, Iran. \\ ${ }^{1}$ Plant Protection Research Department, South Agricultural and Natural Resources \\ Research and Education Center, AREEO, Birjand, Iran. \\ ${ }^{2}$ Senckenberg Natural History Collections Dresden, Museum of Zoology, \\ Königsbrücker Landstraße 159, 01109 Dresden, Germany. \\ ${ }^{5}$ Insect Taxonomy Research Department, Iranian Research Institute of Plant Protection, Agricultural \\ Research, Education and Extension Organization (AREEO), 19395-1454, Tehran, Iran. \\ ${ }^{*}$ Corresponding author: Bmoetamedinia@,iripp.ir \\ ${ }^{2}$ Email: kehlmaier@web.de \\ ${ }^{3}$ Email: mokhtari@uoz.ac.ir \\ ${ }^{4}$ Email: rakhshani@uoz.ac.ir \\ ${ }^{5}$ Email: gilasian@,iripp.ir \\ ${ }^{1}$ urn:1sid:zoobank.org:author:58ABDB36-AB50-4A5A-8B38-EF0B1F9E033B \\ ${ }^{2}$ urn:1sid:zoobank.org:author:3BD2A72C-A88E-4B2F-A22C-7CF522DE6F4D \\ ${ }^{3}$ urn:lsid:zoobank.org:author:84FD880A-22C6-41C8-ACDC-8B347465BA2A \\ ${ }^{4}$ urn:1sid:zoobank.org:author:86C5B3A2-BE3E-4C3B-B0F1-3B69148E0B9B \\ ${ }^{5}$ urn:1sid:zoobank.org:author:A45912ED-BEEB-4733-AC6E-C22ACAFD6F63
}

\begin{abstract}
The genus Dasydorylas Skevington, 2001 is recorded from two provinces in Iran (Sistan-o Baluchestan and Kermanshah Provinces). Dasydorylas derafshani sp. nov. and D. zardouei sp. nov. are illustrated and characterized morphologically and by DNA barcoding of the mitochondrial COI gene. Eudorylas antennalis Kapoor, Grewal \& Sharma, 1987 is transferred to Dasydorlyas (comb. nov.). An existing identification key to the males of the western Palaearctic species of Dasydorylas is complemented to include the newly described species.
\end{abstract}

Keywords. Taxonomy, big-headed flies, Middle East, DNA barcoding, identification key.

Motamedinia B., Kehlmaier C., Mokhtari A., Rakhshani E. \& Gilasian E. The genus Dasydorylas Skevington in Iran, with the description of two new species (Diptera: Pipunculidae). European Journal of Taxonomy 362: 1-13. https://doi.org/10.5852/ejt. 2017.362 


\section{Introduction}

To date, more than 1400 species of Pipunculidae or big-headed flies are recognized, placed into four subfamilies and 20 genera (Rafael \& Skevington 2010; Kehlmaier et al. 2014). However, the diversity is still considered to be poorly known and it is estimated that well over 2000 species exist on a world scale (Skevington \& Yeates 2001). Similar to Syrphidae, adults are frequently seen hovering among vegetation. Male and female pipunculids primarily feed on honeydew, a sugar-rich secretion produced by many Hemiptera, but most of the energy necessary for reproduction is accumulated during the larval stage of the fly (Kehlmaier 2015). Pipunculid larvae develop as endoparasitoids in Tipulidae (Nephrocerus Zetterstedt, 1838) and in various families of Auchenorrhyncha (all other Pipunculidae), but information on host specificity is limited (Skevington \& Marshall 1997; Koenig \& Young 2007; Kehlmaier \& Floren 2010). Females deposit a single egg into the host during flight (Williams 1918; Huq 1985; Rafael \& Skevington 2010). Together with Dryinidae (Hymenoptera) and Strepsiptera, Pipunculidae are considered the most important parasites of Auchenorrhyncha (Freytag 1985). As many species of Auchenorrhyncha are known to transmit plant diseases, Pipunculidae may have the potential to become biological control agents of economically important pest species of leafhoppers.

The genus Dasydoryas Skevington, 2001 was first described in a comprehensive phylogenetic study of world Eudorylini by Skevington \& Yeates (2001). Currently, the genus includes 30 species, occurring in the Afrotropical (nine species), Palaearctic (seven species), Australasian and/or Oriental (11 species) and in the Nearctic and/or Neotropic region (three species) (Skevington \& Yeates 2001; Kehlmaier 2005a, 2005b; Földvári 2013). Being placed within the diverse Eudorylini, the genus can best be separated from other genera by a combination of characters such as the funnel-shaped ejaculatory apodeme, a rather strongly tapering flagellum and a well-developed apical hair fringe on the scutellum (Skevington \& Yeates 2001). Kehlmaier (2005a, 2005b) revised part of the Palaearctic and Oriental faunas, whereas Földvári (2013) revised the Afrotropical members of the genus.

The Iranian fauna of pipunculid flies is poorly known. In previous studies, only 19 species were recorded. Becker (1913) described two new species from Sistan-o Baluchestan Province; Gharali et al. (2008) cited two species from Ilam Province; Kehlmaier \& Majnon Jahromi (2015) listed 15 species from Alborz Province; Motamedinia et al. (2017) described two new species from Sistan-o Baluchestan and Southern Khorasan Provinces. Due to a wide range of habitat diversity, favouring the existence of more than 390 leafhopper species in Iran (Mozaffarian \& Wilson 2016), it is estimated that well over 100 species of pipunculid flies should be present in the country. Collecting material of Dasydorylas from the Eastern (Sistan-o Baluchestan) and Western (Kermanshah) Provinces of Iran revealed two new species of this genus that are described below.

\section{Material and methods}

Specimens were collected by Malaise traps and by hand netting in the eastern and western provinces of Iran (Sistan-o Baluchestan and Kermanshah). The collecting sites are characterized by a warm and dry (Sistan-o Baluchestan Province) or a humid and temperate mountain climate (Kermanshah Province). The traps were situated among herbaceous plants between rows of a Tamarix plantation (Tamarix aphylla (L.) Karst.) (Sistan-o Baluchestan) and between oak trees (Quercus brantii Lindl. and Q. infectoria Oliv.) (Kermanshah) (Fig. 1A-B). Malaise traps were emptied every 14 days. Pipunculids collected by hand net were captured using an aspirator and dropped into $75 \%$ ethanol. After sorting, a series of voucher specimens was preserved in 100\% ethanol and kept in a refrigerator for DNA extraction. Other specimens were dried using the AXA-method according to van Achterberg (2009). The examined material is deposited in the Hayk Mirzayans Insect Museum, Insect Taxonomy Research Department, Iranian Research Institute of Plant Protection, Tehran, Iran (HMIM) and the Senckenberg Natural History Collections Dresden, Museum of Zoology, Germany (SMTD). Male 
genitalia was separated from the abdomen, heated in lactic acid (85\%) for 30 minutes and then placed in a drop of glycerin on a microscopic slide. Illustrations were prepared using an Olympus ${ }^{\mathrm{TM}}$ AX70 microscope and a Motic ${ }^{\mathrm{TM}}$ SMZ-168 stereo microscope equipped with a Moticam ${ }^{\mathrm{TM}} 480$ digital imaging system. A series of ten images were merged using the image-stacking software ZereneStacker v. 1.04. Line drawings of genitalia were traced using the software Inkscape ${ }^{\circledR}$, based on digital photographs, and subsequently mounted in Adobe Photoshop CS3 ${ }^{\circledR}$.

The morphological terminology follows Skevington (2002) and Kehlmaier (2005a), with the following abbreviations being used throughout the paper:

LF:WF $\quad=$ ratio of length of flagellum to its width

LW:MWW = ratio of length of wing to maximum width of wing

LS:LTC = ratio of length of pterostigma to length of third costal segment

LTC:LFC = ratio of length of third costal segment to length of fourth costal segment

LT35:W5 $=$ ratio of length of tergites $3-5$ to maximum width of tergite 5

WT5:LT5 $=$ ratio of width of tergite 5 to its length

T5R:T5L = ratio of length of right margin of tergite 5 to length of its left margin

LT35:WS $8=$ ratio of length of tergites $3-5$ to width of syntergosternite 8

LS8:HS8 $=$ ratio of length syntergosternite 8 to its height

MLE:MWE = ratio of maximum length of epandrium to its maximum width (viewed dorsally)

$\mathrm{LP}: \mathrm{LB} \quad=$ ratio of length of piercer to length of base (viewed laterally)

LDP:LPP $\quad=$ ratio of length of distal part of piercer to length of its proximal part (viewed laterally)

For DNA barcoding, a $658 \mathrm{bp}$ fragment of the 5' end of the mitochondrial coding gene cytochrome oxidase subunit I (COI) was sequenced, using the primer pair LCO1490 and HCO2198 (Folmer et al. 1994). Laboratory procedures are outlined in Kehlmaier et al. (2012). Sequence accession numbers issued by the European Nucleotide Archive (ENA) are provided for each species. Specimens sampled for molecular analysis received an additional label stating an individual voucher number "DNA voucher CKxxx". Uncorrected pairwise genetic distances (p-distance) were computed with MEGA7 (Kumar et al. 2016) using all sites, transitions and transversions with uniform rates and pairwise deletion for missing data.
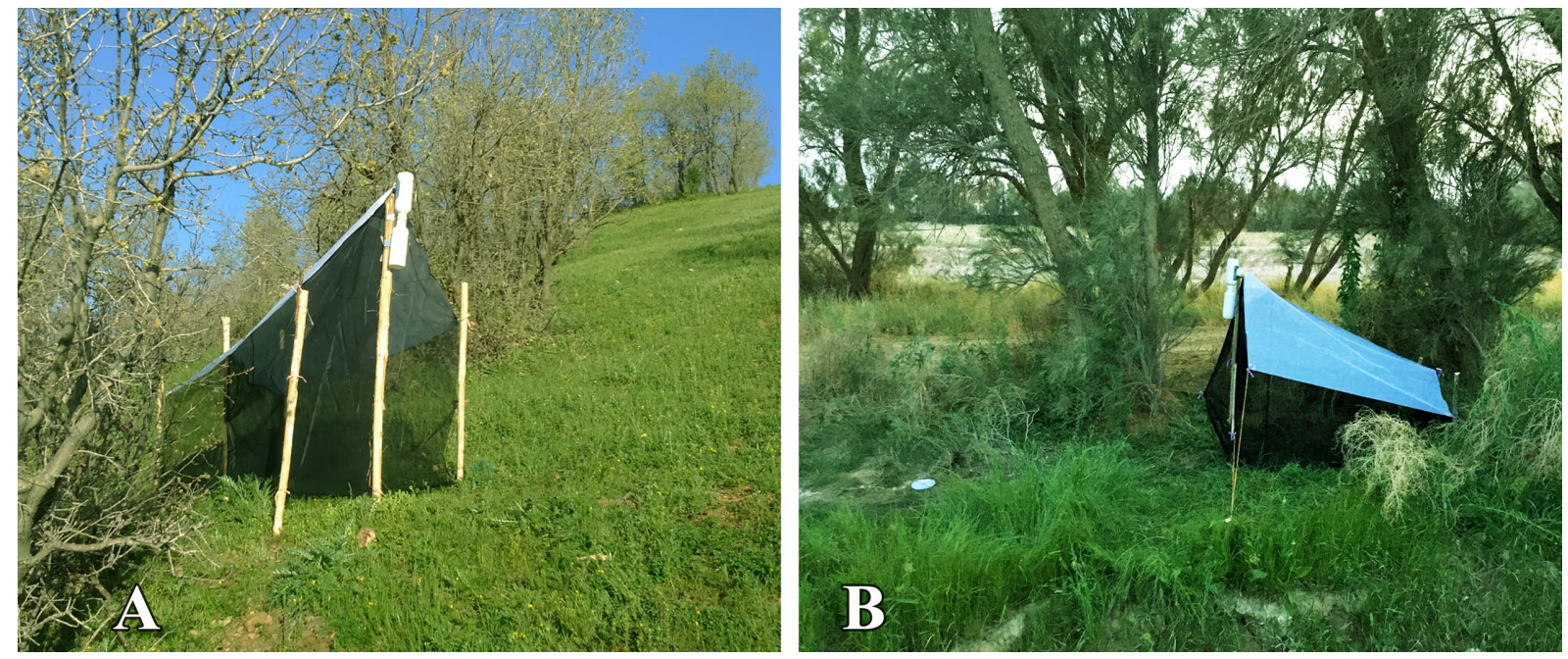

Fig. 1. Malaise traps at collection sites in Iran. A. Kermanshah, Kermanshah Province. B. Zabol, Sistan-o Baluchestan Province. 


\title{
Results
}

\section{Taxonomy}

\author{
Class Insecta Linnaeus, 1758 \\ Order Diptera Linnaeus, 1758 \\ Suborder Brachycera Macquart, 1834 \\ Superfamily Syrphoidea Latreille, 1802 \\ Family Pipunculidae Walker, 1834 \\ Subfamily Pipunculinae Walker, 1834 \\ Tribe Eudorylini Rafael \& De Meyer, 1992 \\ Genus Dasydorylas Skevington, 2001
}

\begin{abstract}
Dasydorylas derafshani Motamedinia \& Kehlmaier sp. nov. urn:1sid:zoobank.org:act:CCFE0068-C682-4C17-A45B-587D2F220575
\end{abstract}

Figs 2-3

\section{Differential diagnosis}

Dasydorylas derafshani sp. nov. is closely related to D. setosus (Becker, 1908), redescribed by Kehlmaier (2005a) and known from the Canary Islands, Morocco and Spain, and to D. gradus Kehlmaier, 2005, described from Israel by Kehlmaier (2005b). The males of all three species have long spines at the apex of the phallic guide that differ in number and direction between species, with $D$. derafshani $\mathrm{sp}$. nov. having eight downward directed spines on either side. Additional diagnostic characters are the differently shaped surstyli and, compared to $D$. setosus, the shorter and more pilose scutellar hair fringe.

\section{Etymology}

This species is named in honour of Hossein Ali Derafshan, who collected the type series material. The surname is to be used as a noun in genitive case.

\section{Material examined}

\section{Holotype}

IRAN: ${ }^{\top}$, Sistan-o Baluchestan Province, Zabol County, Zabol, 31 ${ }^{\circ} 55^{\prime} 10^{\prime \prime} \mathrm{N}, 61^{\circ} 31^{\prime} 17^{\prime \prime} \mathrm{E}, 485 \mathrm{~m}$ a.s.1., 14 May 2015, Malaise trap, H.A. Derafshan leg. (HMIM).

\section{Paratypes}

IRAN: $1 \delta^{\lambda}$, Sistan-o Beluchestan Province, Zabol County, Zabol, 31 ${ }^{\circ} 05^{\prime} 04^{\prime \prime} \mathrm{N}, 61^{\circ} 26^{\prime} 04^{\prime \prime} \mathrm{E}, 482 \mathrm{~m}$ a.s.1., 22 Apr. 2015, Malaise trap, H.A. Derafshan leg. (SMTD; DNA voucher CK863, LT626249); 1 ô,

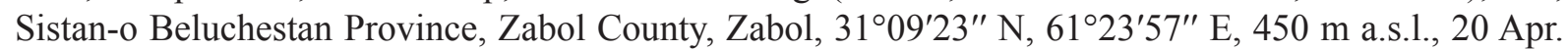
2016, swept from Tamarix aphylla, H.A. Derafshan leg. (HMIM).

\section{Description}

\section{Male}

Body LengTh. 3.3-3.7 mm (excluding antennae).

HEAD. Face dark, silver-gray pollinose. Scape dark, pedicel brown with a pair of short upper bristles and one short lower bristle; flagellum yellow, short tapering and gray pollinose (LF:WF $=2-2.2)$; arista dark, flattened, with thickened base. Eyes converging but not meeting and separated by less than diameter of frontal facets (Fig. 2B). Frons dark, silver-gray pollinose; vertex dark, lacking pollinosity; occiput dark, gray pollinose. 
Thorax. Pleura, prescutum, scutum and scutellum dark but prescutum light yellow at lateral margin. Pleura gray pollinose. Postpronotal lobe pale, gray pollinose and with 3-5 postpronotal setae along upper margin. Prescutum and scutum gray pollinose, with two uniseriate dorsocentral rows of conspicuous setae and supra-alar setae. Scutellum gray pollinose, with an apical fringe of up to ten pale setae (up to $0.1 \mathrm{~mm})$. Subscutellum gray pollinose.

WING. Length: 3.3-3.5 mm. LW:MWW=3-3.2. Wing almost entirely covered with microtrichia. Only small basal cells of wings, e.g., bc, basal of cell c, br, cell bm, basal of cup with somewhat reduced microtrichia. Pterostigma brown and complete (LS:LTC=1.0, LTC:LFC=1.1). $\mathrm{M}_{1}$ gently undulating.

HalteR. Length: $0.4 \mathrm{~mm}$. Base dark, stem narrowly white and knob paler than base, somewhat gray pollinose.

Legs. Coxae dark but yellow on apical margin, gray pollinose. Mid coxa with three brown anterior bristles. Trochanters light brown, partly gray pollinose. Femora dark, distinctly light brown at apex, gray pollinose. All femora bearing two rows of dark, smaller, peg-like anteroventral spines on apical one third. Tibiae light brown, distinctly dark on apical half, gray pollinose with three rows of brown setae on anterior and posterior sides, without apical spines. Hind tibia with a wrinkled indentation midanteriorly. Tarsi light brown and paler than apical half of tibiae, brown pollinose, with some black setae dorsally. Distitarsi brown. Pulvilli shorter than distitarsi.

ABDomen. Ground colour dark. Tergite 1 with four to five brown lateral bristles. Tergites $1-5$ with brown setae. Tergites $1-2$ gray pollinose laterally and dorsally, and tergites $3-5$ gray pollinose laterally extending onto dorsal surface along posterior margin. Tergite 5 asymmetrical. LT35:WT5 $=1.4$, WT5:LT5 $=2.1$ and T5R:T5L $=1.1$. Syntergosternite 8 dark, gray pollinose, without dorsal depression on side of left surstylus. LT35:WS8=2.2. Viewed laterally, syntergosternite 8 higher than long (LS8:HS8=0.6). Viewed caudally, membranous area about one third of the width of syntergosternite 8 , vertically directed, broader in upper half.

Genitalia. Genital capsule in dorsal view: epandrium dark but brownish near surstyli and tergite 5, gray pollinose and longer than wide (MLE:MWE $=1.5$ ). Surstyli paler than epandrium, gray pollinose and symmetrical (Fig. 3E). Both with a broad and rectangular base and a pair of finger-like projections at apices which are bent towards each other by $45^{\circ}$ (Fig. 3E). Genital capsule in ventral view: gonopods
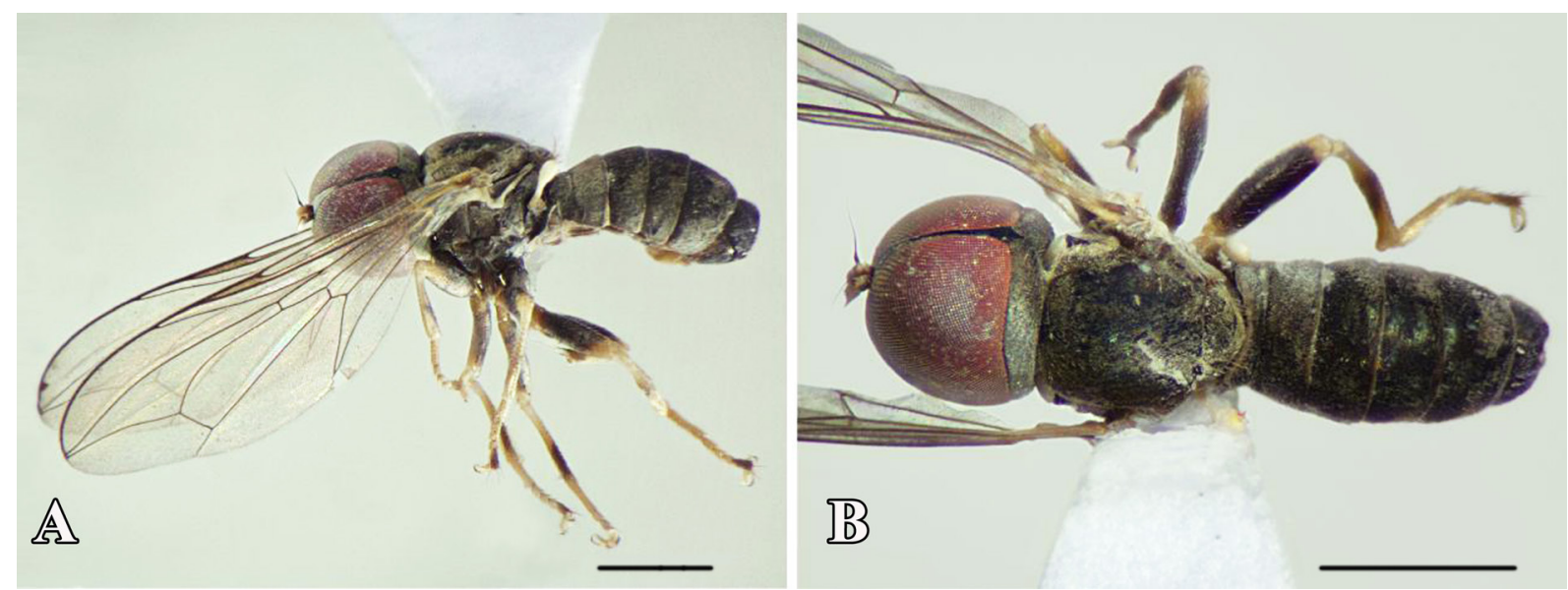

Fig. 2. Dasydorylas derafshani Motamedinia \& Kehlmaier sp. nov., §,, paratype. A. Lateral view. B. Dorsal view. Scale bars: $1 \mathrm{~mm}$. 
rather large and almost symmetrical (Fig. 3A); phallus trifid, narrow, with long and straight ejaculatory ducts (Fig. 3B); phallic guide of medium length, rather broad, on either side with eight downwards directed long spines at its apex (Fig. 3A). Genital capsule in lateral view: epandrium without projecting lobe on either side. Both surstyli distinctly convex and broad in basal two thirds, distally narrowed to form a pair of finger-like processes which are bent towards each other (Fig. 3F-G). Phallic guide broad, gently bent towards surstyli (Fig. 3C). Ejaculatory apodeme funnel-shaped (Fig. 3D).

\section{Female}

Unknown.

\section{Distribution}

Iran.
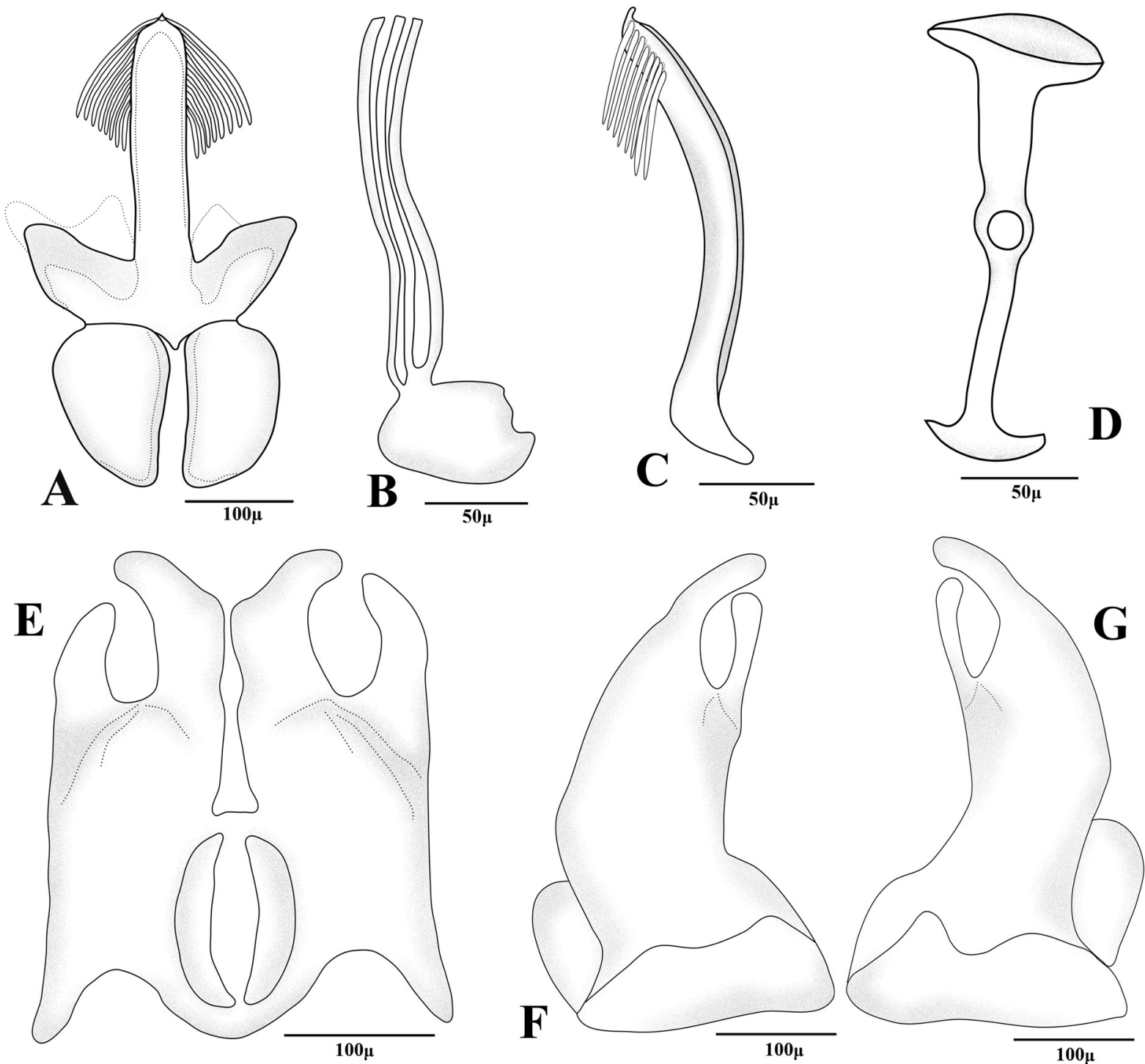

Fig. 3. Terminalia of Dasydorylas derafshani Motamedinia \& Kehlmaier sp. nov., ð̋, paratype. A. Phallic guide, gonopods and hypandrium in ventral view. B. Phallus and membranous sheet in lateral view. C. Phallic guide in lateral view. D. Ejaculatory apodeme. E. Surstyli in dorsal view. F. Left surstylus in lateral view. G. Right surstylus in lateral view. 


\section{Dasydorylas zardouei Motamedinia \& Kehlmaier sp. nov. urn:Isid:zoobank.org:act:C9BA2A47-D425-4FD6-8F6C-074EAAC7219B}

Figs $4-5$

\section{Differential diagnosis}

Dasydorylas zardouei sp. nov. is closely related to the western Palaearctic D. holosericeus (Becker, 1897 ) and D. roseri (Becker, 1897), both redescribed by Kehlmaier (2005a), to the Afrotropical D. evanidus (Hardy, 1949), redescribed by Földvári (2013), to the Oriental D. orientalis (Koizumi, 1959), redescribed by Kapoor et al. (1987), and, judging from the original figures, also to D. antennalis (Kapoor et al., 1987) comb. nov. from southern India. Being morphologically hardly distinguishable from each other, the $D$. holosericeus species group is a good example of how challenging pipunculid taxonomy can be. The males of $D$. zardouei $\mathrm{sp}$. nov. differ from those of the other species by a different sclerotization pattern of the gonopods and by the length of the phallus. The females can be separated by the shorter length of tergite 9 (piercer of ovipositor).

\section{Etymology}

The species is named in honour of Maryam Zardouei who collected the type series material. The surname is to be used as a noun in apposition.

\section{Material examined}

\section{Holotype}

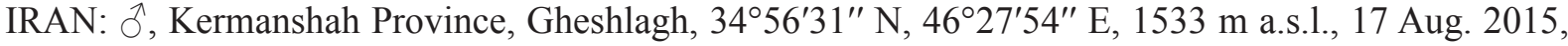
Malaise trap, M. Zardouei leg. (HMIM).

\section{Paratypes}

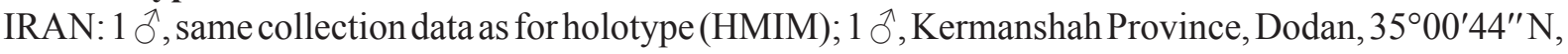
46 12'27" E, 954 m a.s.1., 15 Jun. 2015, Malaise trap, M. Zardouei leg. (HMIM); 1 o, Kermanshah

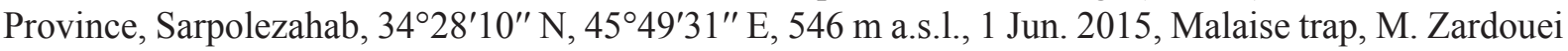
leg. (SMTD; DNA voucher CK885, LT671746); 1 ㅇ, same collection data as preceding (SMTD; DNA voucher CK886, LT671747); 1 \&, same collection data as preceding (HMIM).

\section{Description}

\section{Male}

Body LENGTH. 3.1-3.5 mm (excluding antennae).

HEAD. Face dark, silver-gray pollinose. Scape dark, pedicel brown with three short upper bristles and one short lower bristle; flagellum brown, short tapering and gray pollinose (LF:WF $=2.1-2.2)$; arista dark, with thickened base. Eyes meeting for twelve facets (Fig. 4B). Frons dark, silver-gray pollinose; vertex dark, lacking pollinosity, shining black; occiput dark, gray pollinose.

THORAX. Pleura, prescutum, scutum and scutellum dark, but prescutum light yellow at lateral margin. Pleura gray pollinose. Postpronotal lobe pale, gray pollinose and with 2-3 postpronotal setae along upper margin. Prescutum and scutum gray pollinose, with two uniseriate dorsocentral rows of setae and patches of supra-alar setae. Scutellum gray pollinose, with a fringe of up to six dark setae (up to $0.1 \mathrm{~mm}$ ). Subscutellum gray pollinose, only in dorsocentral area with some brown pollinosity.

WING. Length: 3.2-3.4 mm. LW:MWW=3.1-3.3. Wing almost entirely covered with microtrichia. Only small basal cells of wings, e.g., bc, br, bm, basal of cup cell with somewhat reduced microtrichia. Pterostigma brown and complete (LS:LTC=1.0, LTC:LFC=1.1). $\mathrm{M}_{1}$ straight. 
Halter. Length: $0.5 \mathrm{~mm}$. Base dark, stem narrowly white and knob yellow. Base and stem somewhat gray pollinose.

Legs. Coxae dark, gray pollinose. Front and mid coxae with two dark anterior bristles. Trochanters dark, partly gray pollinose. Femora dark, distinctly yellow at apex, gray pollinose. All femora bearing two rows of dark, smaller, peg-like anteroventral spines on apical one third. Tibiae dark, with basal third and sometimes also apices pale, gray pollinose, with three rows of setae on anterior and posterior side, without apical spines. Hind tibia with some weak wrinkles midanteriorly, bearing one or two stronger bristles. Tarsi brown and paler than tibiae, gray pollinose, with some brown setae dorsally. Distitarsi dark. Pulvilli longer than distitarsi.

AbDomen. Ground colour dark. Tergite 1 with four to five strong lateral bristles, arranged in one row. Tergites $1-5$ with brown setae. Tergites $1-2$ gray pollinose laterally and dorsally, tergites $3-5$ gray pollinose laterally, extending onto dorsal surface along posterior margin. Tergite 5 symmetrical. LT35:WT5 $=1.5$, WT5:LT5 $=1.3$ and T5R:T5L $=1.0$. Syntergosternite 8 dark, brown pollinose, without dorsal depression on side of right surstylus. LT35:WS8 $=2.5$. Viewed laterally, as long as high (LS8:HS8 $=1.0$ ). Viewed caudally, membranous area vertically directed, broader in upper half, occupying about a third of the width of syntergosternite 8 .

Genitalia. Genital capsule in dorsal view: epandrium dark, brown pollinose and wider than long (MLE:MWE =0.8). Surstyli brown, narrowly pale at apices, brown pollinose and rather symmetrical. Both surstyli with a blocky base and a broad finger-like projection at its apical inner corner, bent outward
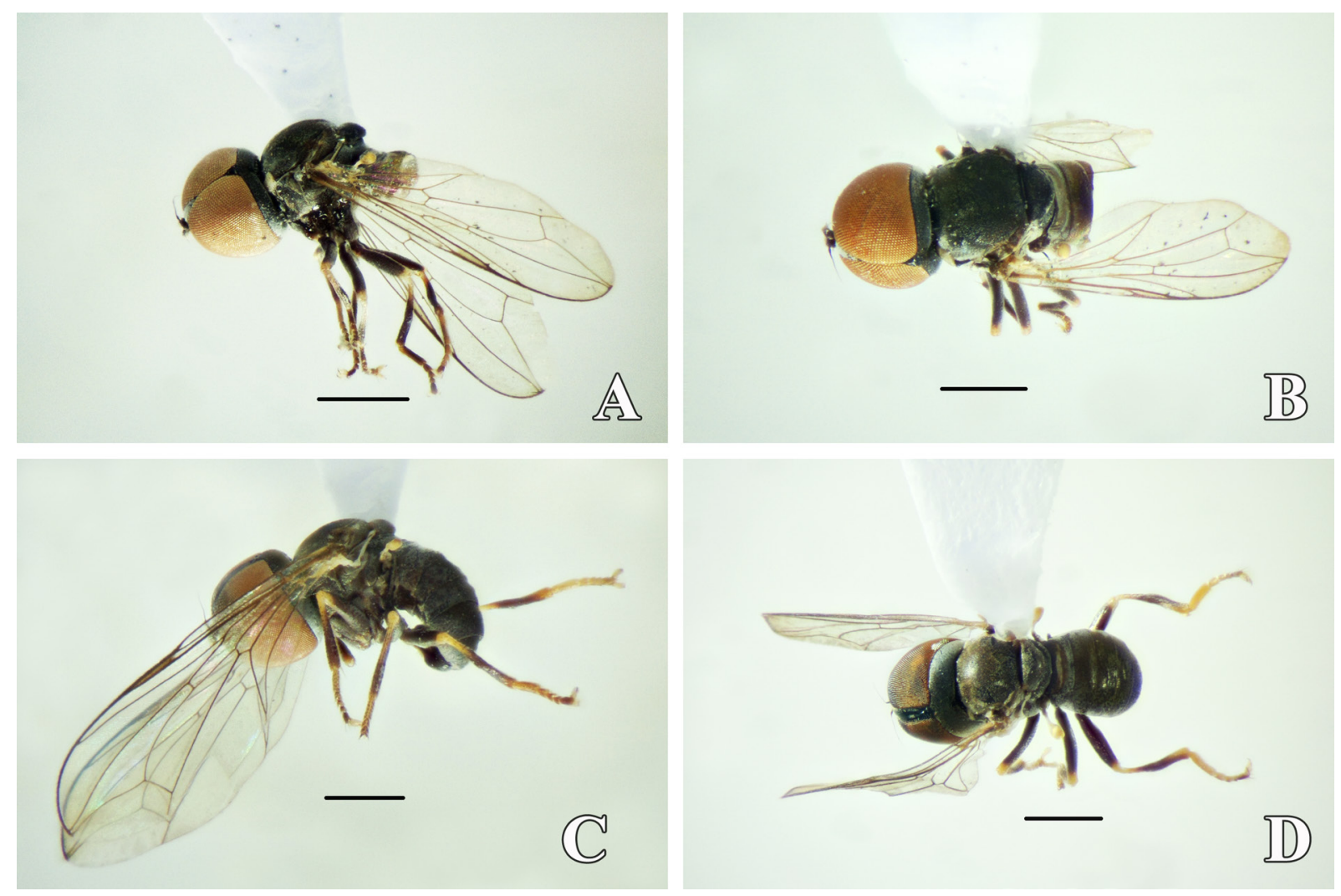

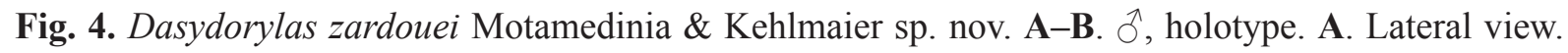
B. Dorsal view. C-D. $q$, paratype. C. Lateral view. D. Dorsal view. Scale bars: $1 \mathrm{~mm}$. 
distally by $90^{\circ}$; base of right surstylus slightly wider than left surstylus (Fig. $5 \mathrm{G}$ ). Genital capsule in ventral view: gonopods minute and symmetrical, with elongated regions of distinctly stronger sclerotization (Fig. 5A); phallus trifid, straight and short (almost reaches apex of surstyli), with a membranous nose at
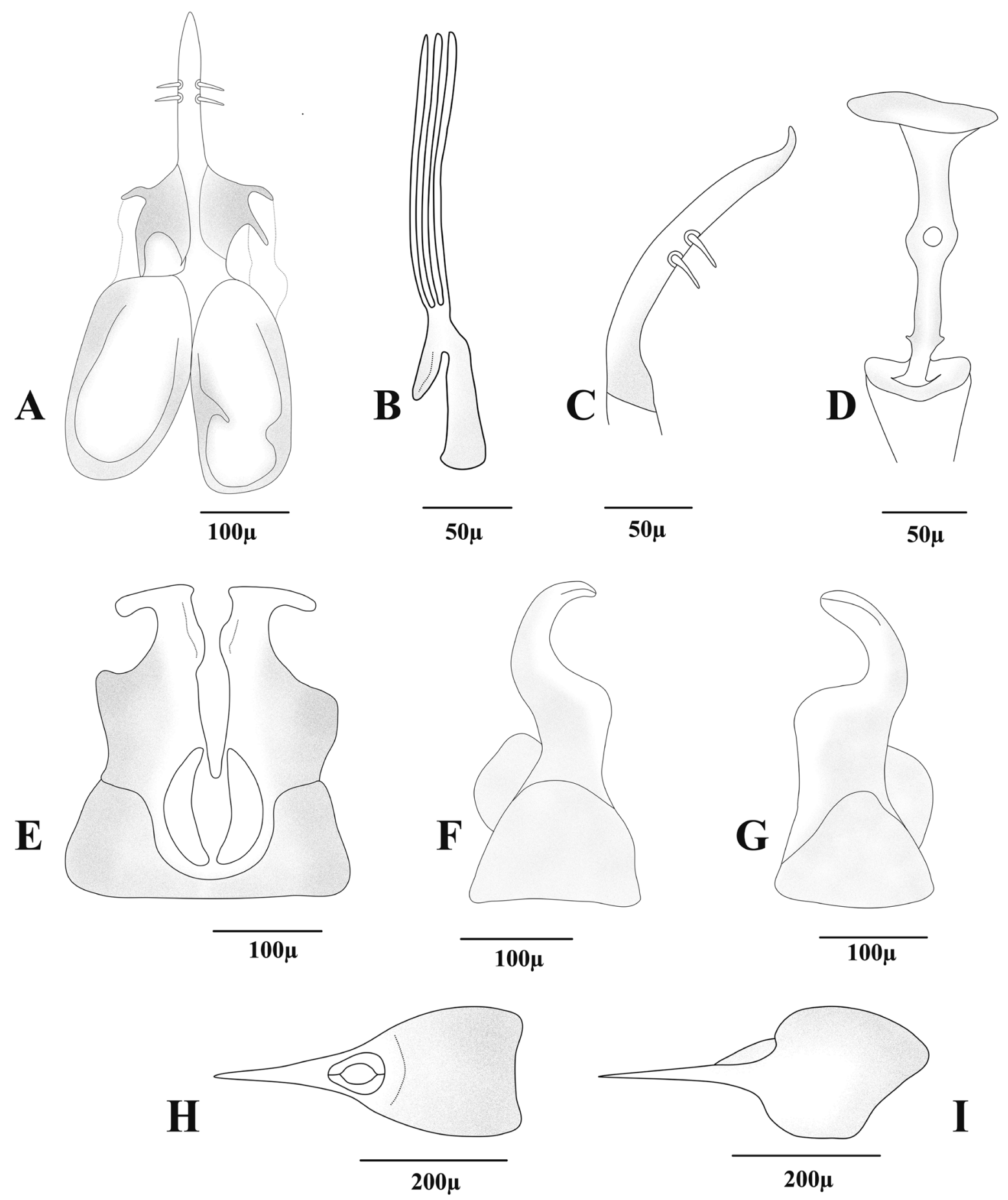

Fig. 5. Terminalia of Dasydorylas zardouei Motamedinia \& Kehlmaier sp. nov. A-G. ふૈ, holotype. A. Phallic guide, gonopods and hypandrium in ventral view. B. Distiphallus with ejaculatory ducts in lateral view. C. Phallic guide in lateral view. D. Ejaculatory apodeme. E. Surstyli in dorsal view. F. Left surstylus in lateral view. G. Right surstylus in lateral view. - H-I. + , paratype. H. Ovipositor in dorsal view. I. Ovipositor in lateral view. 
base (Fig. 5B); phallic guide narrow and straight, with two dorsolateral spines at the end of basal half on either side (Fig. 5C). Genital capsule in lateral view: epandrium without projecting lobe on either side. Both surstyli in basal half broad, in apical half narrowed to form a finger-like process which is bent towards the sternites by $90^{\circ}$ (Fig. 5F-G). Phallic guide bow-like bent towards surstyli (Fig. 5C). Ejaculatory apodeme funnel-shaped (Fig. 5D).

Female (Figs 4C-D, 5H-I)

Body LENGTH. $3.2 \mathrm{~mm}$ (excluding antennae).

HEaD. Scape dark, with two upper bristles. Pedicel with three to four short upper bristles and a pair of short lower bristles. Flagellum paler than pedicel and long, tapering. LF:WF $=3.1$. Eyes separated (Fig. 4D). Front facets enlarged $(0.05 \mathrm{~mm})$. Frons dark, lower half silver-gray pollinose, otherwise shining. Frons with a weak median keel, ending in a tubercle shortly before antenna. Occiput gray pollinose.

THORAX. Postpronotal lobe light yellow, gray pollinose with some light brown bristles. Pleura, prescutum, scutum and scutellum dark, gray pollinose.

WING. Length: $3.1 \mathrm{~mm}$. LW:MWW=3.3. Pterostigma brown and complete (LS:LTC=1.0, LTC:LFC $=0.8$ ).

Legs. Hind coxa paler and larger than fore and mid coxae, with 4-6 black or brownish bristles. Mid femur with two small ventral rows of dark peg-like spines on apical half. Tibiae light brown, distinctly darkened on apical half, without apical spines. Pulvilli longer than distitarsi.

AвDOMEn. Tergites 1-5 gray pollinose laterally, extending onto dorsal surface along posterior margin. Tergites $2-5$ with dark scattered bristles.

Ovipositor. Base of ovipositor dark, dorsally with some gray pollinosity. Viewed dorsally (Fig. 5H), base rather rectangular, without a median longitudinal furrow, longer than wide. Anal opening ovate. Suture between tergite 7 and 8 hardly visible. Piercer yellowish-brown. Proximal part of piercer narrow and triangular. Viewed laterally (Fig. 5I), base of piercer slightly curved, piercer straight and as long as base. $\mathrm{LP}: \mathrm{LB}=1.0 . \mathrm{LDP}: \mathrm{LPP}=1.9$.

\section{Distribution}

Iran.

\section{DNA barcoding}

Uncorrected pairwise genetic distances (p-distance) were calculated from partial mitochondrial COI based on a dataset comprising five out of six European species of Dasydorylas - D. filiformis Kehlmaier, $2005(\mathrm{n}=1)$, D. holosericeus $(\mathrm{n}=1)$, D. horridus (Becker, 1897) $(\mathrm{n}=4)$, D. roseri $(\mathrm{n}=4)$ and D. setosus $(\mathrm{n}=1)$ - and will be published in a forthcoming larger project (Kehlmaier et al. in prep.). Based on this, Dasydorylas derafshani sp. nov. stands closest to D. setosus, differing by $11.2 \%$. The third Iranian species of the genus, $D$. horridus, differs by $14.3 \%$ (LK391738), whereas $D$. zardouei sp. nov. is differentiated by $12.6 \%$. The latter species stands closest to $D$. holosericeus $/ D$. roseri, differing by a minimum interspecific p-distance of $6.8 \%$ and $11.6 \%$ respectively. From D. horridus it is distinguished by $11.7 \%$. 


\section{Key to males of West-Palaearctic Dasydorylas Skevington, 2001}

For generic identification, follow the key in Kehlmaier (2005a) to couplet 18.

1 Abdominal tergites densely covered with rather long bristly hairs ( $\delta^{\lambda}$ : up to $0.07 \mathrm{~mm}$ ). (Dorso-) lateral fan of tergite 1 with about 13 strong, dark bristles of different length. Male genitalia as in Kehlmaier 2005a: fig. 15a-h

D. horridus (Becker, 1897)

- Abdominal tergites less densely covered with shorter hairs (up to $0.05 \mathrm{~mm}$ ). (Dorso-) lateral fan of tergite 1 with about 8 bristles at the most

2 Flagellum extremely long tapering, filiform (LF:WF $>5.5$ ) (Kehlmaier 2005a: fig. 18i). Syntergosternite 8 without membranous area. Eyes meeting for about ten times diameter of ocellus. $\mathrm{F}: E M=1: 0.5-0.6$. $\mathrm{LTC}: \mathrm{LFC}=0.6-0.8$. Surstyli and genitalia as in Kehlmaier 2005a: fig. 18a-h .......

D. filiformis Kehlmaier, 2005

- LF:WF $<4.0$. Syntergosternite 8 with membranous area. Eyes meeting for 15 to 20 times diameter of ocellus. F:EM=1:1.0-1.2. $\mathrm{LTC}: \mathrm{LFC}>1.6$

3 Scutellar hair fringe with 6 very strong bristles (up to $0.2 \mathrm{~mm}$ ). Flagellum very long, tapering $(\mathrm{LF}: \mathrm{WF}=3.7-3.9)$

D. setosus (Becker, 1908)

- Scutellar hair fringe with up to 14 shorter bristles (up to $0.07 \mathrm{~mm}$ ). Flagellum shorter (LF:WF= $2-2.3)$

4 Phallic guide with up to 14 long spines on each side, pointing upwards into different directions. Each surstylus distally with a single outward bent finger-like projection (Kehlmaier 2005b: fig. 12i) D. gradus Kehlmaier, 2005

- Phallic guide with less than 10 long spines on each side .5

5 Phallic guide with 8 downwards directed long spines on each side. Each surstylus with a pair of finger-like projections which are bent towards each other (Fig. 3E)

D. derafshani Motamedinia \& Kehlmaier sp. nov.

- Phallic guide with only 2 spines on each side

6 Gonopods with elongated regions of distinctly stronger sclerotization (Fig. 5A). Phallus short and length of ejaculatory ducts shorter than length of surstyli

D. zardouei Motamedinia \& Kehlmaier sp. nov.

- Gonopods without elongated regions of stronger sclerotization. Ejaculatory ducts of phallus longer than surstyli

7 Dorsolateral spines of phallic guide rather strong, situated at end of basal half (Kehlmaier 2005a: fig. 14a-b). Surstyli as in Kehlmaier 2005a: fig. 14d, j-k. Phallus with long ejaculatory ducts (Kehlmaier 2005a: fig. 14h). Membranous area occupies about half the width of syntergosternite 8 (Kehlmaier 2005a: fig. 14e)

D. holosericeus (Becker, 1897)

- Dorsolateral spines of phallic guide somewhat smaller and situated after basal third (Kehlmaier 2005a: fig. 16a-b). Surstyli as in Kehlmaier 2005a: fig. 16d, j-k. Phallus with shorter ejaculatory ducts (Kehlmaier 2005a: fig. 16h). Membranous area occupies about a third of the width of syntergosternite 8 (Kehlmaier 2005a: fig. 16f)

D. roseri (Becker, 1897)

\section{Discussion}

Based on morphology and DNA barcoding, the present paper introduces two new species of Dasydorylas from Iran, increasing the number of known species of Pipunculidae from this country to 21 . In previous studies of this family, only one species ( $D$. horridus) was recorded from Alborz Province in northern Iran (Kehlmaier \& Majnon Jahromi 2015). In general, Dasydorylas must be considered a species-poor genus, represented by only nine Palaearctic taxa. The discovery of the two newly described Dasydorylas 
and other previously unnamed species (Motamedinia et al. 2017) is not very surprising, considering not only the limited amount of research carried out on big-headed flies in Iran, but also the geographic location of the Middle East in general and the large habitat diversity present in Iran in particular. Being situated at the "border triangle" of the Palaearctic, Afrotropical and Oriental zoogeographic regions, the Middle East and Iran act as a transition zone of these realms. An extensive and long-lasting survey would be essential in order to assess the true diversity of Pipunculidae and other taxa present in Iran.

\section{Acknowledgements}

Our special thanks to H.A. Derafshan (Zabol) and M. Zardouei (Kermanshah) for providing the material from Sistan-o Baluchestan and Kermanshah Provinces. The contribution by E. Rakhshani was supported by grant no. UOZ-GR-9517-2 from the University of Zabol for Malaise trapping in Sistan-o Baluchestan Province.

\section{References}

Becker T. 1913. Persische Dipteren von den Expeditionen des Herrn N. Zarudny 1898 und 1901. Annuaire du Musée Zoologique de l'Académie Impériale des Sciences de St. Petersbourg 17: 503-654.

Földvári M. 2013. Taxonomic revision of the Afrotropical species of the tribe Eudorylini (Diptera, Pipunculidae). Zootaxa 3656: 1-121. https://doi.org/10.11646/zootaxa.3656.1.1

Folmer O., Black M., Hoeh W., Lutz R. \& Vrijenhoek R. 1994. DNA primers for amplification of mitochondrial cytochrome c oxidase subunit I from diverse metazoan invertebrates. Molecular Marine Biology and Biotechnology 3: 294-299.

Freytag P.H. 1985. The insect parasites of leafhoppers and related groups. In: Nault L.R. \& Rodriguez J.G. (eds) The Leafhoppers and Planthoppers: 423-467. John Wiley and Sons, New York, USA.

Gharali B., Kehlmaier C., Gadiri Rad S. \& Kamangar S. 2008. Pipunculid flies of Iran: important and overlooked parasitoids. In: Manzari S. (ed.) Proceedings of the 18th Iranian Plant Protection Congress, Volume I: Pests: 99. University of Bu-Ali Sina, Hamedan, Iran. Asna Printing Group, Hamedan, Iran.

Huq S.B. 1985. Über Eudorylas subterminalis Coll. (Dipt., Pipunculidae) als Parasit bei Cicadellidae (Homoptera) in Berlin (West). Anzeiger für Schädlingskunde, Pflanzenschutz, Umweltschutz 58: 147149. https://doi.org/10.1007/BF01903133

Kapoor V.C., Grewal J.S. \& Sharma S.K. 1987. Indian Pipunculids (Diptera: Pipunculidae), a Comprehensive Monograph. Atlantic Publishers \& Distributors, New Delhi.

Kehlmaier C. 2005a. Taxonomic revision of European Eudorylini (Insecta, Diptera, Pipunculidae). Verhandlungen des Naturwissenschaftlichen Vereins in Hamburg (Neue Folge) 41: 45-353.

Kehlmaier C. 2005b. Taxonomic studies on Palaearctic and Oriental Eudorylini (Diptera: Pipunculidae), with the description of three new species. Zootaxa 1030: 1-48. https://doi.org/10.11646/zootaxa.1030.1.1

Kehlmaier C. 2015. Big-headed flies do occasionally imbibe nectar (Diptera: Pipunculidae). Studia Dipterologica 21 (1): 91-93.

Kehlmaier C. \& Floren A. 2010. Pipunculidae (Diptera) collected by canopy-fogging in the Białowieża Forest (Poland), including first host records and larval descriptions of two Palaearctic Nephrocerus Zetterstedt. Studia Dipterologica 16 (1/2): 169-181.

Kehlmaier C. \& Majnon Jahromi B. 2015. On the presence of Pipunculidae (Diptera) in Iran. Studia Dipterologica 21 (1): 29-36.

Kehlmaier C., Michalko R. \& Korenko S. 2012. Ogcodes fumatus (Diptera: Acroceridae) reared from Philodromus cespitum (Araneae: Philodromidae), and first evidence of Wolbachia Alphaproteobacteria in Acroceridae. Annales Zoologici 62: 281-286. https://doi.org/10.3161/000345412X652819 
Kehlmaier C., Dierick M. \& Skevington J.H. 2014. Micro-CT studies of amber inclusions reveal internal genitalic features of big-headed flies, enabling a systematic placement of Metanephrocerus Aczél, 1948 (Insecta: Diptera: Pipunculidae). Arthropod Systematics and Phylogeny 72 (1): 23-36.

Koenig D.P. \& Young C.W. 2007. First observation of parasitic relations between big-headed flies, Nephrocerus Zetterstedt (Diptera: Pipunculidae) and crane flies, Tipula Linnaeus (Diptera: Tipulidae: Tipulinae), with larval and puparial descriptions for the genus Nephrocerus. Proceedings of the Entomological Society of Washington 109: 52-65.

Available from https://biodiversitylibrary.org/page/31078523 [accessed 10 Oct. 2017].

Kumar S., Stecher G. \& Tamura K. 2016. MEGA7: Molecular Evolutionary Genetics Analysis version 7.0 for bigger datasets. Molecular Biology and Evolution 33 (7): 1870-1874.

https://doi.org/10.1093/molbev/msw054

Motamedinia B., Kehlmaier C., Mokhtari A., Rakhshani E. \& Gilasian E. 2017. Discovery of the genus Claraeola Aczél in Iran with the description of two new species (Diptera: Pipunculidae). Zootaxa 4227: 563-572. https://doi.org/10.11646/zootaxa.4227.4.6

Mozaffarian F. \& Wilson M.R. 2016. A checklist of the leafhoppers of Iran (Hemiptera: Auchenorrhyncha: Cicadellidae). Zootaxa 4062: 1-63. https://doi.org/10.11646/zootaxa.4062.1.1

Rafael J.A. \& Skevington J.H. 2010. Pipunculidae (big-headed flies). In: Brown B.V., Borkent A., Cumming J.M., Wood D.M., Woodley N.E. \& Zumbado M.A. (eds) Manual of Central American Diptera 2: 793-803. NRC Research Press, Ottawa.

Skevington J.H. 2002. Phylogenetic revision of Australian members of the Allomethus genus group (Diptera: Pipunculidae). Journal of Insect Systematics and Evolution 33: 133-161.

https://doi.org/10.1163/187631202X00109

Skevington J.H. \& Marshall S.A. 1997. First record of a big-headed fly, Eudorylas alernatus (Cresson) (Diptera: Pipunculidae) reared from the subfamily Cicadellinae (Hemiptera: Cicadellidae), with an overview of pipunculid-host associations in the Nearctic region. Canadian Entomologist 129: 387-398. https://doi.org/10.4039/Ent129387-3

Skevington J.H. \& Yeates D.K. 2001. Phylogenetic classification of Eudorylini (Diptera, Pipunculidae). Systematic Entomology 26: 421-452. https://doi.org/10.1046/j.0307-6970.2001.00160.x

van Achterberg C. 2009. Can Townes type Malaise traps be improved? Some recent developments. Entomologische Berichten 69: 129-135.

Williams F.X. 1918. Some observations on Pipunculus, a fly which parasitizes the cane leafhopper, at Pahala, Hawaii, February 11-April 25, 1918. Hawaiian Planter's Record 19: 189-192.

Manuscript submitted: 13 January 2017

Manuscript accepted: 27 March 2017

Manuscript published: 26 October 2017

Topic editor: Gavin Broad

Desk editor: Danny Eibye-Jacobsen

Printed versions of all papers are also deposited in the libraries of the institutes that are members of the EJT consortium: Muséum national d'Histoire naturelle, Paris, France; Botanic Garden Meise, Belgium; Royal Museum for Central Africa, Tervuren, Belgium; Natural History Museum, London, United Kingdom; Royal Belgian Institute of Natural Sciences, Brussels, Belgium; Natural History Museum of Denmark, Copenhagen, Denmark; Naturalis Biodiversity Center, Leiden, the Netherlands; Museo Nacional de Ciencias Naturales-CSIC, Madrid, Spain; Real Jardín Botánico de Madrid CSIC, Spain. 